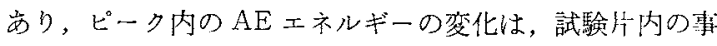
象の数，主なわち，新たに逆方向に降伏する降伏サイトの 数の分布を示していると結諭された。

(2) 活方向の降伏は，AE ピーク内て不均一江生じてお り，その!特の降伏応力とAEピークより得られた降伏サイ 卜の分作より，変形抵抗に上める back stress の分价と平 均值を求める新しい手法を提案した。

(3) 求められた平均back stress の变形抵抗に対する割 合は銅，アルミ二ウムては 15〜20\%, $\alpha$-Brass $22 \%$, SUS 304 では 37\%であった。あた，アルミニウム単綕晶の值 も多結晶の值と汪とえど同一であった。これらの值は，バ ウシンガー応力ー歪関係とるよく対応し， back stress 犆は，バゥシンガー効果を表す聂も息い表示值と思かれ る.

(4) 平均 back stress の值は, 小さい昰領域で歪之 其比值線的增加し，以後，飽和する傾向にある。乙かし ながら，back stress と装形抵抗の比は，查に依存せず一 定である。た，back stress と变形抵抗の比注，雪速度 にはほとんど依存していない。

（5）低埧焼鐩を行ならことにより，他の成分は一定 で，back stress 成分のみが急速に消隇し，再結晶が生ず る以前にバウンンカー效果は消失していることをこの結果 は示している。このことは，また，forest stress 成分は， 再結晶と共に消失する成分と考えられる。

(6)以上の結果より，back stressを支配するサイト は，粒界に関係なく，加工硬化組織化存するるのであ り，back stress は，主に主すべり系の転位による硬化成 分，forest stressは，2次転位に支配された硬化成分と して理解しらるものである。
以上AEの湘定により，back stress 成分を求め得るこ とを示してきたが，本研究を遂行するにあたり，日大生産 工学部 青木顕一郎教授，東大宇宙研 丹羽 登教授，渠林 一应工学博上，用中博，加藤 明，荻島解治諸氏の協力 を党た。ここに感謝する次第である。

\section{文献}

(1) R.M.Fisher and J.S.Ially : Can.J. Phys., 45 (1967), 1147.

(2) P.G.Gills and M.A.Hamstad : Mat. Sci. Eng., $14(1974), 103$.

(3) T.Kishi, H.Tanaka, R.Horiuchi, Y.Obata and K. Aoki : Scripta Meta., 9(1975), 1023.

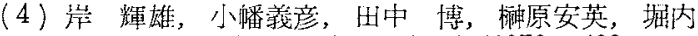

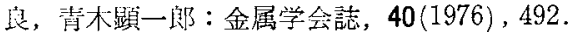

(5) P.B.Hirsch : The Physics of Metals, 2 Defects, Cambridge, Univ. Press, (1975), 189.

(6) G.Moan, C.M. Sargent and I.D. Embury: Proc. 3rd Int. Conf. Strength of Metals and Alloys, (1973), 41.

（7）五马勇雄，尖 烧雄：塑性と加工，10(1969)，863.

(8) L.M.Brown : Acta Met., 21(1973), 879.

(9) T.Mori and K.Narita : Acta Met., 23(1975), 85.

(10) J.D.Atkinson, L.M.Brown and W.M.Stobbs : Phil. Mag., 30(1974), 1247.

(11) K.Kuribayashi, H.Tanaka, T.Kishi, R. Horiuchi and A. Katoh : Proc. $3 r d$ AE Symp., Tokyo, (1976), 271.

(12) J.Eisenblätter, P. Jax and H. J. Schwalbe: Proc. 2nd AE Symp., Tokyo, (1974), 1.

(13) A. S. Iyer and P. Gordon : Trans. Met. Soc. AIME, 215(1959), 729 .

(14) T.Hasegawa, T.Yakou and S.Karashima: Mat. Sci. Eng., 20(1975), 267.

(15) K.Tanaka and T.Mori : Acta Met., 18(1970), 931.

(16) 田中紜一：学位論文(東王大)。

\title{
塑性変形における $\mathrm{AE}$ の振幅分布
}

$$
\begin{aligned}
& \text { 岸輝 雄* 加藤明** } \\
& \text { 栗 林一彦* 堀内 良* }
\end{aligned}
$$

Teruo Kishi, Akira Katoh, Kazuhiko Kuribayashi and Ryo Horiuchi : Amplitude Distribution of Acoustic Emission Signals in Plastic Deformation. The amplitude distribution of acoustic emission due to plastic deformation was studied in relation to deformation properties of $\mathrm{Al}, \mathrm{Cu}, \mathrm{Al}-\mathrm{Mg}, \mathrm{Al}-\mathrm{Si}, \alpha$-Brass, $\alpha-\mathrm{Fe}$ and SUS 304 . The integrated distribution function of $\mathrm{AE}$ amplitudes can be given by

$$
I\left(V_{t}\right)=k \exp \left(-a V_{m}^{t}\right),
$$

where $I\left(V_{t}\right)$ shows the cumulative number of ringdown countings, whose amplitude are equal to or greater than a given threshold voltage $V_{t}, m$ and $k$ are constants defined as the threshold exponent and the threshold pre-exponent respectively. The threshold exponents may be classified to three categories : $0.5,1$ and 2 , respectively. The case of $m=2$, which represents

* 東京大学宇宙航空研究所 (Institute of Space and Aeronautical Science, The University of Tokyo, Tokyo)

** 東京大学大学院 (Graduate School, The University of Tokyo, Tokyo) 
Gaussian distribution, was observed in high purity $\mathrm{Cu}$ and $\mathrm{Al}$, and corresponds to the socalled continuous-type of AE. The case of $m=0.5$, on the other hand, corresponds to the burst-type of $\mathrm{AE}$ and was observed in SUS 304 and Al-Si alloy. The case of $m=1$ shows the mixture mode of continuous and burst-type of $\mathrm{AE}$, and was observed in $\mathrm{Al}-\mathrm{Mg}, \alpha$-Brass and $\alpha-\mathrm{Fe}$.

These threshold exponent $m$ values are strongly connected with the metallurgical factors, which control the flow deformation, such as Peierls potential, solute atoms, dispersion particles, and stacking fault energy. The variation of $m$ values between 0.5 and 2.0 can be explained by simple $\mathrm{AE}$ models, characterized by the terms of stress concentration and the frictional stress.

The stress concentration (elastic stored energy) controls the magnitude of discontinuos deformation. The frictional stress controls the relaxation rate of the energy release.

(Received January 31, 1977)

\section{I. 緒言}

新しい材料評価法として。Acoustc Emission(以下 $\mathrm{AE})$ は，その敏感な動的特性の河に，結晶塑珄，材料強 度の分野汇扎いて，有效な研究手段飞なり得る可能性を有 する。弾性波としての AEは，弾性体内の運動方程式を满 足するものであり(1)(2)，局所的变形が急速に生じた時の弹 性エネルギーの解放に伴って生ずると考壳られる(3)，微視 的に見ると，AE パルスが生成，伝播する采件と乙ての位 相のそ万った振動(4)，即号弾性变形に扣いては，多くの転 位が，同相の運動を行なった時化 AE ペルスが生ずるもの であり ${ }^{(5)}$ ，このことは，若干巨視的観点に立つと，材料内 の様々の形の不均一性(例之ば，粒界，介在物，転位絪等) に起因する応力集中によってもたらされる不均一変形と $\mathrm{AE}$ が対応していると定義することるできる(6).

このような材料，変形様式们敏感な $\mathrm{AE}$ は，当然各材料 によりその挙動は異なり， $\mathrm{AE}$ パルスを支配する， $\mathrm{AE}$ エ ネルギー，振幅分布，周波数スペクトラムに材料特有の登 動が観測される。

Eisenblätter (7)は，引張り試験に伴う $\mathrm{AE}$ パターンを実 效値電圧を用い 5 つのパターンに分類したがここれは， $\mathrm{AE}$ の発生挙動を知るには，有力なるのであったが，金属 学的因子と結びつけられるような形での定量性は，これだ けでは得られていない。

一方，振幅分布の測定に関しては，突発型 $\mathrm{AE}$ の多いき 裂進展に伴う $\mathrm{AE}$ は，々の尖顽值(peak 電圧) を測定し， その分布が，地震に打斿る Ishimoto-Iida の関保式により 良く整理されることが報告されている(8)(9)。しかしなが 占，連続型 $\mathrm{AE}$ が支配的な塑性変形火和いては，このよう な整理をすることはできず，わずかに Eisenblätter(7)は， 正規分布，ポアンン分布に上り，Ono ${ }^{(10)}$ は，レーリー分布 に上る整理法を提案しているがこれら関倸式と变形を文 配する金属学的因子の間に今の所，何ら定量的関係を見出 し得ないといらのが現状である。

本報告では, 各種金属材料の塑性変形に伴う $\mathrm{AE}$ の振幅 分在をリングダウン計数法で求め，これらの結果は，正規 分布蛙よび，それを搪張した指数関数で整理しらると共
に，その関係式の意味を検詰し，また得ら礼た結果を，金 属学的因子々関係して裞明し，振幅分布の物理的意味を明 らか汅したものである。

な执，閏波数スペクトラムの測定は，测定にかかる $\mathrm{AE}$ 総エネルギーを求めるには重要であるが，その定量的貺定 は現在の所，難しく，また周波数により $\mathrm{AE}$ パターンがそ 礼程大き変化しないという実験結果より(11)，各材料の AE 挙動の相刘測定で比較しらるものと考学た。

\section{II. 実 験 方 法}

実験に用いた $\mathrm{AE}$ 测定のブロック図が Fig.1亿示され ている，試験片つかみ部(未变形領域)近傍に探触子は取つ けられたが，高感度を得るために，直径 $8.0 \mathrm{~mm}, 140 \mathrm{kHz}$ 共振周波数のものが用いら机ている。電圧增幅は, 約 $70 \mathrm{~dB}$ の堌幅率，雑音除去を兼ねたフィルターは，通過帯域 $20 \mathrm{k}$ 〜200 kHz のバンドパスフィルターで漓る. 得られた信号 は、一度データーレューダー(TEAC.R-410)に記録され， 再生時に，振幅弁別器 (NF.AE-921)のしきい值電王を変 化させることにより，カウンター(NF.AE-931)で計数し， DA 変換後，ペンレコーダーでの記録を繰り返すことによ り，振幅分有を求めた。李た同時に電在計により，AE 実 效值出力電压を記録している。

用いた試験片は，平行部 $4 \times 6 \times 40 \mathrm{~mm}$ の板状試験片で ありヂック部の雑音除去のために，つか及部はあら かじめ万力によるプレス加工を行ない，Kaiser 効果を利

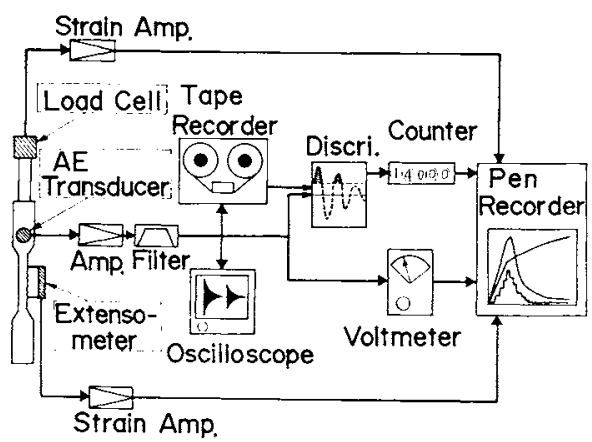

Fig.1 Block diagram of the electronics for the measurement of $\mathrm{AE}$. 
用した雑音除去を試みた。ダミーによる些験絬果より，汪 とんど，治具接触による雑音は問題にならないことが半明 した。

本実験に用いた供試材およびその最終熱処理条件は，

Table 1 亿一括して示されている。多結晶材料としては，

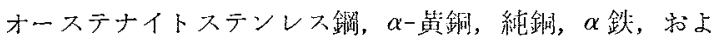
び Al-Si 分散硬化合金が用いら礼た，単結晶は，ブリッ ジマン法で作られたものであり，純 $\mathrm{Al}$ ，Al-Mg 合金が用

Table 1 Chemical compositions and final heat treatments of the specimens.

\begin{tabular}{l|l|c}
\hline \hline Material & $\begin{array}{l}\text { Chemical } \\
\text { composition }\end{array}$ & Heat treatment \\
\hline $\mathrm{Al}$ & $99.99 \% \mathrm{Al}$ & - \\
$\mathrm{Al}-\mathrm{Mg}$ & $\mathrm{A} 1-3 \% \mathrm{Mg}$ & - \\
$\mathrm{Al}-\mathrm{Si}$ & $\mathrm{A} 1-1.2 \% \mathrm{Si}$ & $580^{\circ} \mathrm{C} \times 1 \mathrm{~h}(\mathrm{~W} . \mathrm{Q})$. \\
$\mathrm{Cu}$ & OFHC Copper & $500^{\circ} \mathrm{C} \times 1 \mathrm{~h} \mathrm{~h} \times 1 \mathrm{~h}$ \\
$\alpha-\mathrm{BraSS}$ & $\mathrm{Cu}-30 \% \mathrm{Zn}$ & $450^{\circ} \mathrm{C} \times 0.5 \mathrm{~h}$ \\
$\mathrm{SUS} 304$ & $18 \% \mathrm{Cr}-8 \% \mathrm{Ni}$ & $1150^{\circ} \mathrm{C} \times 0.5 \mathrm{~h}(\mathrm{~W} . \mathrm{Q})$. \\
$\alpha-\mathrm{Fe}$ & $\mathrm{Fe}-0.017 \% \mathrm{C}$ & $920^{\circ} \mathrm{C} \times 1 \mathrm{~h}$ \\
\hline
\end{tabular}

W.Q. : Water Quenched

\section{single crystal}
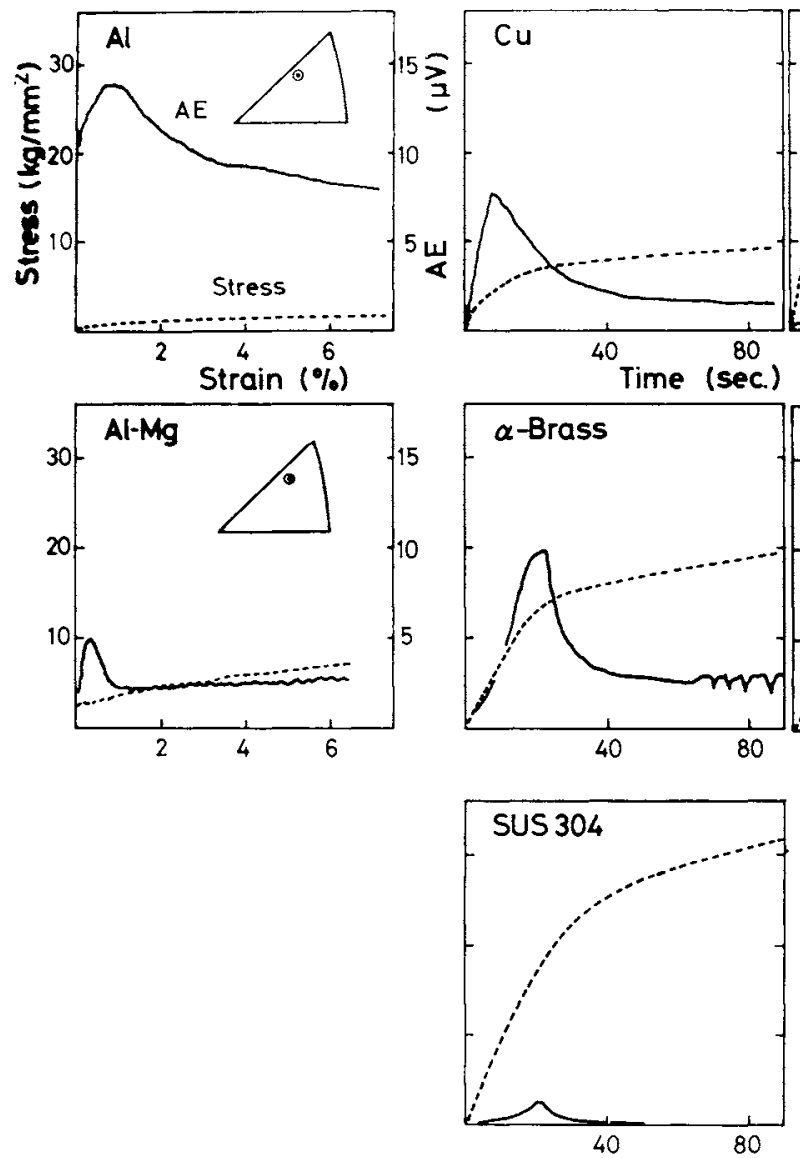

poly crystal

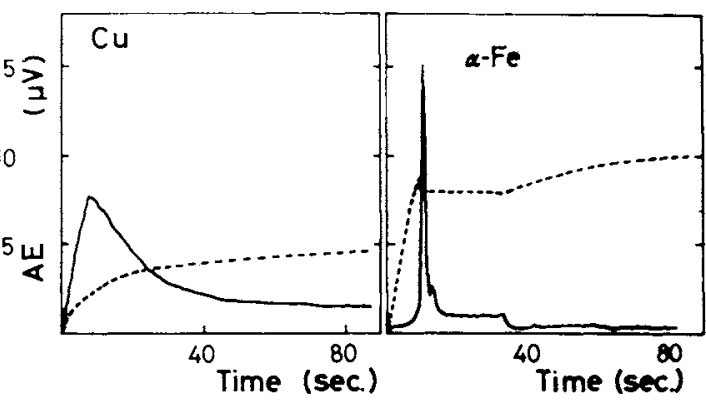

Al-Si

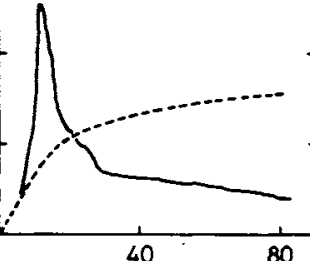

Fig.2 AE patterns expressed by R.M.S. voltage in uniaxial tensile deformation.
いられている，A1-Mg 合金は，固溶体合金、A1-1.2\% Si 合金は，分散硬化合金と考えられる．Al-Si 合金の時効条 件は，最大強度の得られるものであり，その時の分散粒子 の徍は約 $0.1 \mu$ であった。

用いた試験機は，AUTO GRAPH 10 T であり，引張り

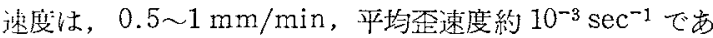
り，実験は常温で行なった。

\section{III. 実 験 結 果}

用いた村料の実効值出力電压 $(\mu \mathrm{V})$ によるパターンが，

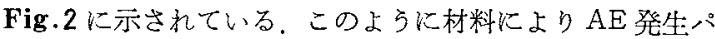
ターンは大きく異なっているが，との材料に和いても，降 伏近傍に大きな出力が観察されている。それ故に，このピ 一クの極大值近傍(peak state)括よび，変形が進んで $\mathrm{AE}$ レベルがほぼー定に澾した定常領域(steady state)で振幅 分布を求めてみた。

リングダウン計数の積分モード振幅分布の整理は，すで に Eisenblätter ${ }^{(7)}$ Kり報告されているが，彼の報告し た関係式のみでは，すべての実験式を整理することはでき ない，そこでそれを搪張し て，多くの塑形変形に伴り リングダウン計数を表わし 得る関係式として，著者ら は，次の実験式による整理 を試みた。

$$
\begin{aligned}
& I\left(V_{t}\right)=k \cdot \exp \left(-a V_{t}^{m}\right) \\
& \text { ここで, } V_{t} \text { はしい值 }
\end{aligned}
$$
電生 (threshold voltage) であり，I(Vt)はVtより 大きな振幅を持つリングダ ウン計数率である。 $k$ 拉よ び $m$ は定数であり，kは threshold pre-exponent, $m$ \& threshold exponent と名づけらた(12)，mの值 は以下に述べるように材料 の金属学的特性亡関係つけ られ，いわば材料因子と呼 ばれるものであるが，実験 的心は 3 つに大別される。

Fig.3は種々の金属につい ての積分モード振幅分布を 示して和り，銅多結晶につ いては横軸は $V_{t}^{2}$ をり， $\alpha$-黄鍼については $V_{t}$, SUS 304 については $V_{t}^{1 / 2}$ をと。 ているここれらはそれぞれ。 


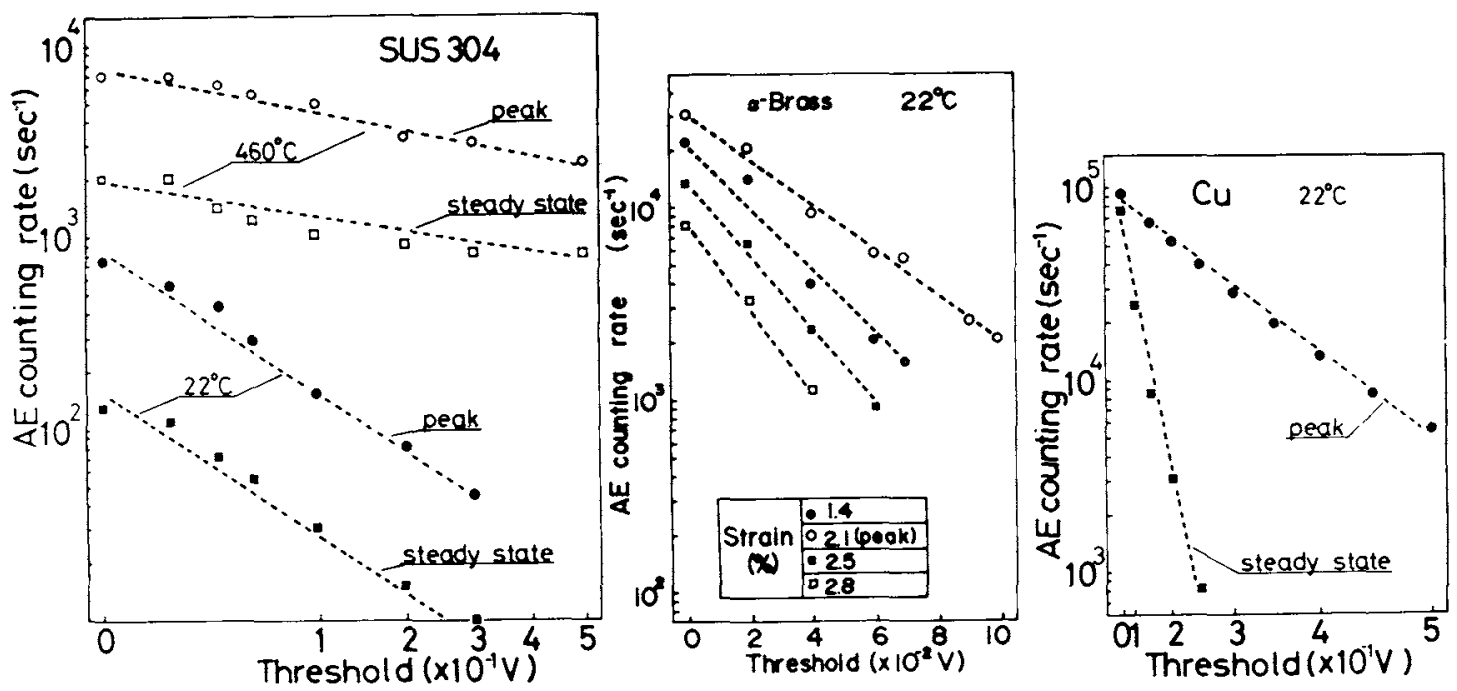

Fig.3 The relation between $I\left(V_{t}\right)$ and $V_{t}$ values in (a) $\mathrm{Cu}$ (b) $\alpha$-Brass (c) SUS 304 .

$m=2,1,1 / 2$ に対応らけられていることが容易に理解され る。この $m$ の值は周一材料では霍の量，拉よび基本的に は変形温度に依存せず，ほぼ一运の值をとっている。

一方 $k$ の值は $m=1$ 较よび $m=2$ の場合には活ほ用いた $\mathrm{AE}$ 変換子の共振周波数に近い值をとるが， $m=1 / 2$ の場 合には必ずしも一定値をとるわけではない(Table 2).

Table 2 Experimental values of the threshold exponent $m$ and the threshold preexponent $k$ and wave types of emission signals.

\begin{tabular}{c|c|c|c}
\multicolumn{3}{c}{$I\left(V_{t}\right)=k \cdot \exp \left(-a V_{t}^{m}\right)$} \\
\hline \hline$m$ & Type of AE & Example of material \\
& & Single crystal & Poly crystal \\
\hline 2 & continuous & $\mathrm{Al}$ & $\mathrm{Cu}$ \\
1 & burst & $\mathrm{Al}-\mathrm{Mg}$ & $\alpha$-BSass, $\alpha-\mathrm{Fe}$ \\
$1 / 2$ & & $\mathrm{SUS} \mathrm{304, \textrm {Al } - \mathrm { Si }}$ \\
\hline
\end{tabular}

これらの振輻分有に対応したAE信号のオシロスコープ による波形観察結果を示したのが Photo.1である. $m=2$ の銅に和いては典型的な連続型AEが観察されている。こ れに対し， $m=1$ の $\alpha$-鉄の場合には，突発型成分がかなり 連続型に混在して和り， $m=1 / 2$ D SUS 304 では，突発型 $\mathrm{AE}$ が支配的とい觉。

以上握幅分有は式 $(1)$ で整理でき， $m$ と波形の間には， 上い対応関係が成立して和り， $m=2$ は連続型であり， $m$ 值が小さくなるに良い，突登型成分が堌加してくる。 Table 2 にその結果が記されている。

\section{IV. 検討}

以上塑珄変形に伴 $5 \mathrm{AE}$ リンダダウン計数率が，式 (1)の関係式汇より整理され，且つ $\mathrm{AE} の m$ 值が波形の 観察結果，即ち連続型，突発型波形とよく対态することが
明らかにされた。

ここでは、ッングダウン計数率における 意味および，単純な $\mathrm{AE}$ 発生千デルを基礎に $m$ と，金属の 変形を支配する因子との相関について検討し， $m$ が变形様 式を示す有效なパラメーターになり得ることを示した。

\section{1. リングダウン計数と $\boldsymbol{m}$ 值}

ランダムな $\mathrm{AE}$ 事象の分何としの連続型 $\mathrm{AE}$ が，正規分 推を示し，式( 1 )に标いて $m=2$ で示されるのは妥当なこ とである。そして実験的に得られた $m$ の最小值が $m=1 / 2$ で㐫り，突発型 $\mathrm{AE}$ を示していることは， $m=1 / 2$ にお る振幅分有 $I\left(V_{t}\right)$ が，智発型 $\mathrm{AE}$ 信是のりングダウン計数 と関係していることが理解される。

さて，1つの突発型 $\mathrm{AE}$ パルスは一般に Fig.4のよ5 な淢衰形を示し，そのリングダウン部数は

$$
n_{e}=f_{o} / \beta \ln \left(V_{p} / V_{t}\right)
$$

で与兄られる(13)。ここでVっは父頭值電压， $V_{t}$ はしきい 值電压，foは变換子の共振周波数， $\beta$ は減衰係数を表わし

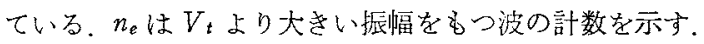
ここで式 (1)和ける $m=1 / 2$ に相当する $I\left(V_{t}\right)$

$$
I\left(V_{t}\right)=k \exp \left(-a V_{t}^{1 / 2}\right)
$$

を式(2)の関保式で与えられる舆型的な突発型 AE に対し ての振幅分布を用いて近似することの妥当性を検討する。 まず $a$ の值をパラメーターとした場合

$$
I\left(V_{t}\right) / n_{e}=\left(k \beta / f_{o}\right) \exp \left(-a V_{t}^{1 / 2}\right) / \ln \left(V_{p} / V_{t}\right)
$$

の計算結果か Fig.5(a)，(b)に示されている。ただん扔 よび $f_{0}$ は雪には低存しない等数であり， $k$ も基本的には 歪とは独立な定数である，Fig.5(a)は $V_{p}=1(\mathrm{~V}) ，(\mathrm{~b})$ は $V_{p}=0.5(\mathrm{~V})$ 《対しての部算結果である。 $m=1 / 2$ である SUS 304 で通常は $V_{p} \approx 1(\mathrm{~V})$ (たたし $70 \mathrm{~dB}$ 増幅後) 程度

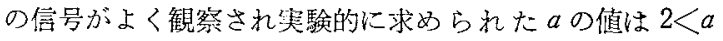
く4であった。 

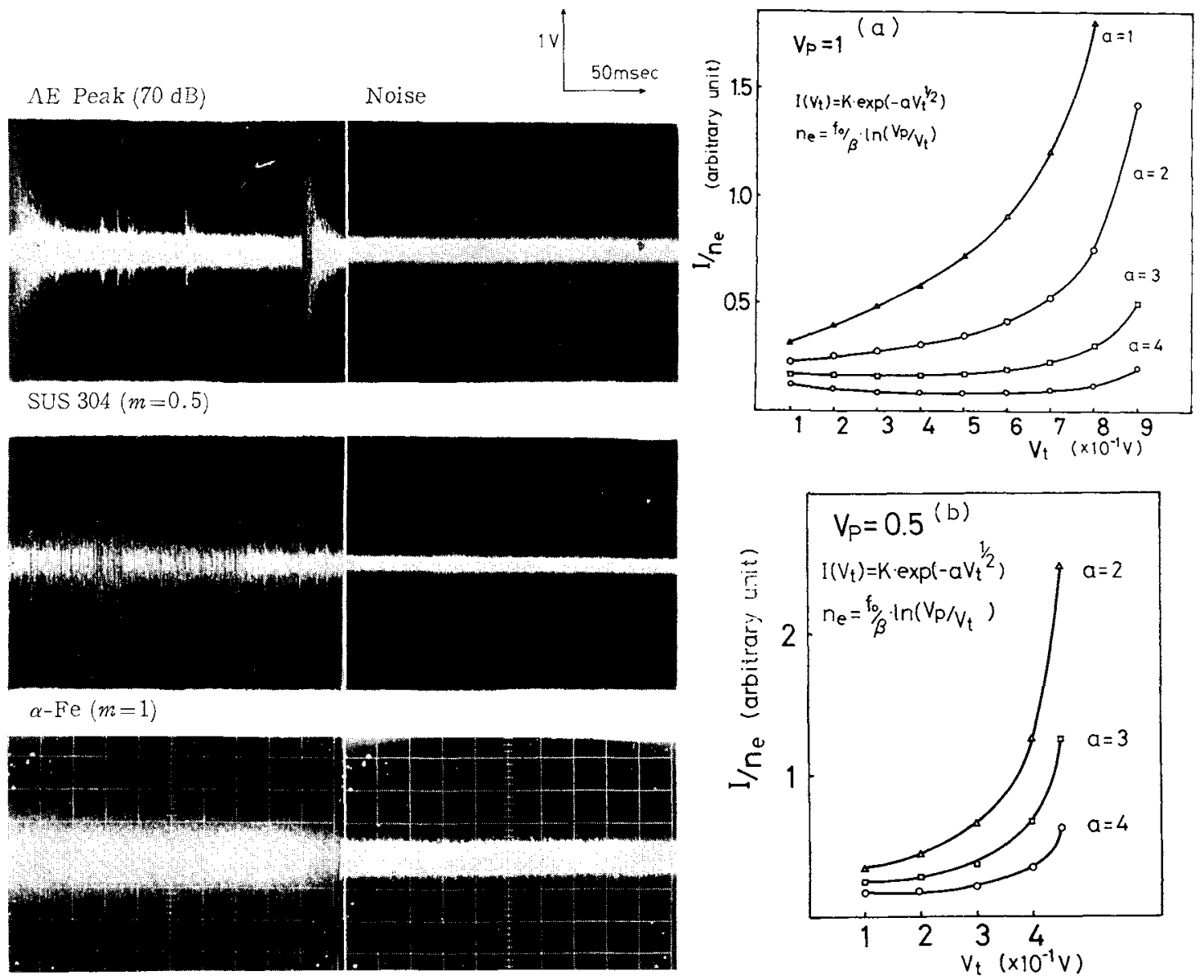

$\mathrm{Cu}(m=2)$

Photo. 1 Oscilloscopic photographs of AE signals in SUS $304, \alpha$-Fe and Cu.

Fig.5 The ratio of integrated ringdown count rates $I\left(V_{t}\right)$ to sinusoidal decreasing counts $n_{e}$ is plotted in arbitrary unit against the threshold voltage $V_{t}$.

\section{Schematic Diagram}

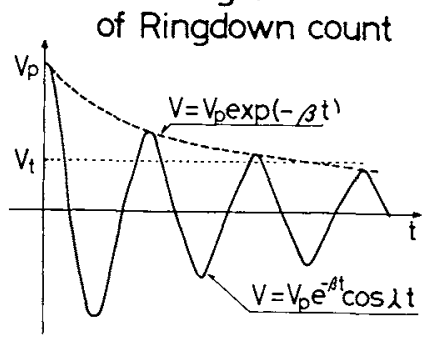

$n_{e}=f_{0 / \beta} \ln \left(V_{p / V_{t}}\right)$

fo resonant frequency

$\beta$ damping factor

is

$I\left(V_{t}\right)=K \exp \left(-a V_{t}^{1 / 2}\right)$

Fig.4 Schematic representation of a damped sinusoid singnal. Threshold voltage is expressed as $V_{t}$.

図から明らかなよらにVtの大きな領域を除いて式(3) は近似的江式(2)に等しく，したがって通常の AE の測定 に和いては

$$
I \approx k_{0} \cdot n_{\theta}
$$

の形で表示されらることになる。ここで $k_{0}$ 㤝突発形 $\mathrm{AE}$ の事数数を表わしている.

上記の考察において問題となるのは $V_{p}$ の分布状態が無 視できない場合である。その上うな場合には式（５）快その ま恋の形では適用され党ないこと时明らかであるが，AE

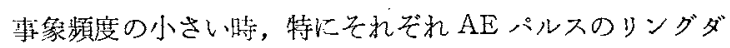
ウンの重なりが完全に無視できるよらな場合には，基本的 には上記の関係が満足される。したがって式(3)，すなから $m=1 / 2$ (特に SUS 304 に物いて) は突発型 AE のリングダ ウン計数をよく近似しているものであり，m=1の状態は $m=2$ の連続型 $\mathrm{AE}$ と $m=1 / 2$ の突発型 $\mathrm{AE}$ の混在状態と して近似的汇あらわれるもの之考党ると，AE の振幅分们 において連続型 $(n=2)$ から突発型 $(m=1 / 2)$ Kいたるりン 
グダウン計数率が式(1)のmの值の変化によりすべて表 示されていることが明らかになる。

\section{2. 振幅分布と RMS 電圧}

つぎにこうして求められた積分モード振幅分布 $I\left(V_{t}\right)$

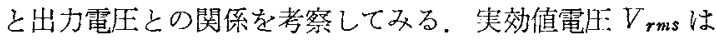
振幅分倠 $I\left(V_{t}\right)$ を用いることにより，つぎのように定義で きる。

$$
\text { R.M.S. }=\left(\frac{\int_{0}^{\infty} V_{t}^{2} N\left(V_{t}\right) d V_{t}}{\int_{0}^{\infty} N\left(V_{t}\right) d V_{t}}\right)^{1 / 2}
$$

$こ こ に I\left(V_{t}\right)=\int_{V_{t}}^{\infty} N\left(V_{t}\right) d V_{t}$ であり，N(Vt)はしい 値電生が $V_{t}$ と $V_{t}+d V_{t}$ の間の $\mathrm{AE}$ 波の数をあらわして いる。式(6)に式(1)を代入することにより $m=2$ の㭙は R.M.S. $=1 / \sqrt{a}, m=1$ の時には R.M.S. $=1 / a, m=1 / 2$ の時にはR.M.S. $=\sqrt{24} / a^{2}$ 占得られる。 Table 3 に式 （1）の振幅分行より上の関係から計算 LたR.M.S.cal.と 交流実効値電圧計を用いることにより值接的に求められた R.M.S.exp. が示されている. $m=2$ の銅，捄よび $n=1$ の $\alpha$-黄銅の場合には，R.M.S.exp.と振幅分柯から求めた R.M.S.cal.は 10\%から $30 \%$ 程度の愦差は示しているる のの，此較的さい一致を示して拈り，相対的に比較するこ との妥当性を示している、乙れに対して $m=1 / 2 の \mathrm{SSU}$ 304 では R.M.S.exp.はR.M.S.cal.にくらべて非常に小

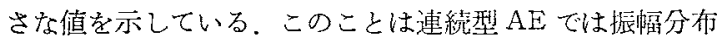
から求めた R.M.S.cal, 加実祭のAE 信号の大きさをよく 表わしているが、突発型 AEに执いてはR.M.S.exp.はAE の絶対值を過小評価していることを意昧している。これ は，交流実効值電圧計はその底答特性（洔定数は 100２00 msec) に拈いて振幅变動の大きい突発型信号を時間的に 平均化して測定しているためと考えられる。したがって $\mathrm{AE}$ 事象頻度の小さな突発型 AE の測定に対しては，交流 実效值電压計は必ずても十分な效力があるとはいるないこ とになる。しかしながら 扱いは効力をもつことが結論できる。

Table 3 The experimentally obtained R.M.S. voltages and the R.M.S. voltages evaluated from the amplitude distribution.

Summary of R.M.S. value

\begin{tabular}{c|c|c|c}
\hline & & R.M.S.col. $(\mu V)$ & R.M.S.exp. $(\mu V)$ \\
\hline \multirow{2}{*}{ Cu } & Peak & 17.7 & 20.1 \\
& Steady state & 14.2 & 14.7 \\
\hline \multirow{2}{*}{$\alpha$-Brass } & Peak & 12.4 & 18.6 \\
& Steady state & 8.9 & 11.1 \\
\hline \multirow{2}{*}{ SUS 304 } & Peak & 41.8 & 9.9 \\
& Steady state & - & 2.8 \\
\hline
\end{tabular}

\section{3. $\boldsymbol{m}$ 值の金属学的因子との関係}

threshold exponentである $m$ を浔配する金属学的因 子としては,

(1) 直溶原子

(2) パイエルスカ

(3) 析出分散粒子

(4) 積層欠陼エネルギー 等が挙げられる.

$m=2$ の正规分有は，ランダムな $\mathrm{AE}$ 事象を示しており， そ礼故捙続型 $\mathrm{AE}$ が観察されている，ｍが小さくなるとい ら事は，AE 事象の原因となる素過程が，このランダムな 状態から偏倚してくる状態に対応している。

この桭幅分有を説明するために，䉮単な $\mathrm{AE}$ 発生モデル として，Fig.6(a)を考えてみる。市要素 $V^{*}$ に力が扣わ り，運動方程式を満足した形でAE强性波が放出される。 Malen (3)の解析結果によると，この領域 $V *$ に打算性 ディストーション $\varepsilon^{*}$ が大きく，且つそれの生ずる時間 $\Delta t$ が小さい程，大さな $\mathrm{AE}$ 加観察される。微視的にみると， こらして AE パルスが生ずる条件はV*の中で，転位群が 位相のとるった策目運動をすることであり(5)このこと は，巨視的には，この領域が，急速な不均一変形を生ずる ことを意昧している ${ }^{(6)}$ 。このよらな不均一変形が生ずる原 因として，Fig.6(a)k示したよらな，何か材料内の不均一 性(粒界，セル組織 etc.) の存在により，微視的他力集中 $\tau_{b}$

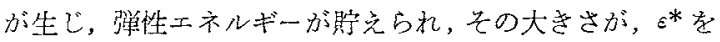
支配し， $\mathrm{AE}$ 発生の原因となりらる。事実，既に著者らは，

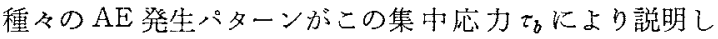
らることを示している(6).

一力， $\Delta t$ はこの領域における転位運動の速度により支 配されるので，粘性的な摩擦㐫力 $\tau_{f}$ の大きさが，直接 $\Delta t$ を支配することになる。この $\tau_{f}$ 成分が高い，体心立方金

(a)

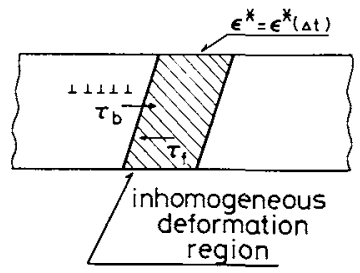

(b)

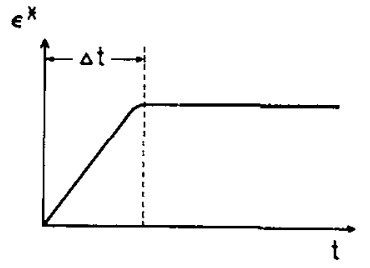

Fig.6 The model of AE considered from the standpoint of the inhomogeneous deformation, characterized by the stress concentration $\tau_{b}$ and frictional stress $\tau_{f} \cdots$ (a) The relation between plastic destortion $\varepsilon^{*}$ and relaxation time $\Delta t$ in the upper model....(b) 
属， $\mathrm{A} 1-\mathrm{Mg}$ 固溶体合金での $\mathrm{AE} レ$ ベルの低下は，この関 係をよく示している。

さて，登生 $\mathrm{AE}$ パルスは，このよらな $\tau_{f}, \tau_{b}$ に律速され るものであるが，振腷分椎も当然こ机らに依存したものに

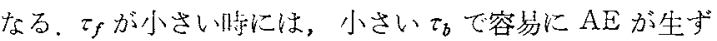
ることになり当然その頻度もランダムなものになり，正䙺

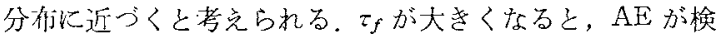

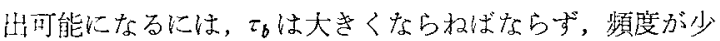
なくなると共に，小さいランダムな信号ではなく大きな突 発型のbのに移行与る。东九，一力 $\tau_{f}$ 方变化しなくとも

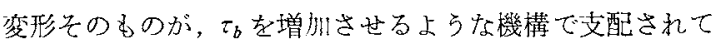
いる場合には，やはり突発型の割合が増える可能性があ る、いず机せよ，変形を律速する金属学的闪子により $\tau_{f}$ が大きくなってるてが大さなっても生ずるAEはラン ダムな正規分们は保証されなくなり，m值は低下するすの と思われる。実験結果を照らし合わせると，A1-Mg 合金 では， $\mathrm{Mg}$ 溶質原子の固溶飞より，摩察応力 $\tau_{f}$ が上昇し たと考光られるが，その時の振幅分有は， $m=2$ の正规分 有からずれ， $m=1$ になっている。なた，体心立方金属之 しての $\alpha$-鉄は，パエルス力に上る摩擦応力が大き， その $m$ 值は，ほぼ $m=1$ の值を取っている。分散硬化材

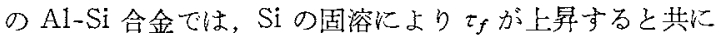
変形々のものが, Si 分散物心律速され転位の分散物による bowing outに上る自己ェネルギ一の上昇により，弾珄工

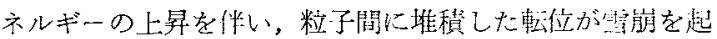
こすような過程により, 変形が律速され，耐者の効果より 突登型の $\mathrm{AE}$ の頿度が増し， $m$ は $1 / 2$ に近ついたものと考兄 られる。

また，積層久䍀エネルギーが低い材料(SUS 304)では交 叉汇りが起き難く，動的回復は小さくなり,転㕸は 2 次元的 配列をとり， $\tau_{b}$ は上昇した事になり，その崩㙖はランダム なるのに程遠く, 突発型 $\mathrm{AE}$ が生じ, $m=1 / 2$ の值をとっ

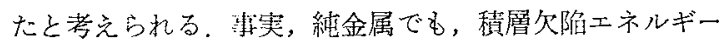
の低い $\mathrm{Ag}$ 等は， $\mathrm{Cu}, \mathrm{A} 1$ に比較して，mは小さく，ほぼ $m=1$ が報告されて和り，5 at％以上のA1 を含告 $\mathrm{Cu}-\mathrm{Al}$ 合金では $m=1 / 2$ が示されている(14).

以上, 実験的に求めた式 (1)に和壮る threshold exponent $m$ は，変形を支配する金属学的因子と関係し，徽視 的応力集中 $\tau_{b}$ と艺の緩和に㝒与する摩擦力 $\tau_{f}$ のモデルに よりよく㜔明され得るものでする。これらの結果より，塑 性変形区伴う $\mathrm{AE}$ の振幅分布の測起は，從来の電瓜，ある

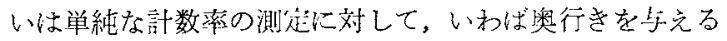
ものであり，変形機棈との效応についても一歩立ら入った 議論の可能性を示唆している。

\section{V. 結 論}

塑性変形汇伴うAEをより微視的に金属学的因子女結び つけて理解する一手法として，拢偪分悑の測定を行ない次
の結果を得ている，用いた材料は，銅， $\alpha$-黄銅， $\alpha$-鉄，才一

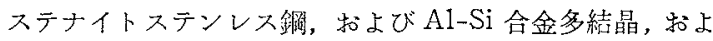
び $\mathrm{A} 1, \mathrm{~A} 1-\mathrm{Mg}$ 単結晶である。

（1）塑性変形に件らリングダウン計数の積分モード振幅 分们 $I\left(V_{t}\right)$ は㳄の指数関係で良く整理されることが実賖的 飞訝明された。

$$
I\left(V_{t}\right)=k \exp \left(-a V_{t}^{m}\right)
$$

$V_{t}$ はされ值電瓜， $I\left(V_{t}\right)$ は $V \geq V_{t}$ に括けるリングダウ ン計算率を示し， $a, k, m$ は知数であり，kは threshold pre-exponent, $m$ は threshold exponent と名づけてい z.

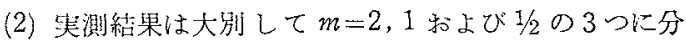
けて考えられる。波形観察によると， $m=2$ は典型的な連 続型 $A E$ を示し， $m$ 少小さくなるにつれて突登型 $A E$ の成 分加増加し， $m=1 / 2$ は塑性変形にかかわらず，ほぼ突発

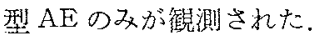

(3) $120 \mathrm{AE}$ 事象の尖頭值を $V_{p}$, 減衰係数を $\beta$, 周波

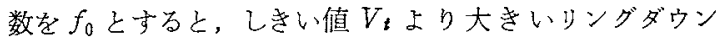
計数 $n_{e}$ は，次の形で与光られた。

$$
n_{e}=f_{0} / \beta \ln \left(V_{p} / V_{t}\right)
$$

計算によると，式(1)における $m=1 / 2$ に相当する $I\left(V_{t}\right)$ は，式(2)と比例関係にあり， $m=1 / 2$ は, 突発型 $\mathrm{AE}$ の リングダウン係数を示すことが䛧明された，即ち式( 1 )は 広く正規分椎 $(m=2)$ 加突発型 AE $(m=1 / 2)$ 女表方しら る実驗式である。

（4）式（1）から計算で求めた R.M.S.電任は， $m=20$ 場会には，実測値とよく一致したが， $m=1 / 2$ では奏測值 は小さな值を示している。これはR.M.S.電死計の応答 速度の追従性によると思わ机るが，電圧湘定は，课続型

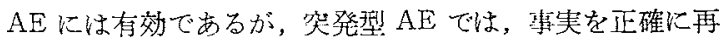
現しているか疑わしい。

(5) $m$ の值は, 変形礿式を律速する金属学的因子と関 係している、ハイエルスカの大きさ，溶質原子の存在によ り，また，分散粒子の存在により，mの值は減少し，突発 型 $\mathrm{AE}$ の頻度が増している。束た，積層欠陷エネルギーが 低くなるとｍの值が小さくなるといえる。

(6)これらの関係は，不均一変形を生ぜしわる微視的応 力集中 $\tau_{b}$ が大きく，且つ粘性的な摩察応力 $\tau_{f}$ が大きい と，ランダムな転位運動が，保訨され難くなるというモデ ルで統一的に解釈された。即台，固溶原子の存在，打よび パイエルス打の增加により $\tau_{f}$ が増加し, 分散物の存在,

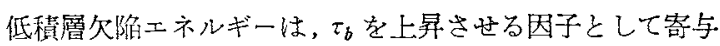
している.

以上，AEに括りる振幅分行の測定は，電王による測 定に比較し，金属の内部に入りこんだ変形機構と結びつい た情報を与克得るものである。 


\section{文献}

(1) C.Kittel：固体物理学入門上，宇野他訳，丸善， 133.

(2) T.Mura: Mathematical Theory of Dislocations, ASME, (1969) , 25.

(3) K. Malen and L.Bolin : Phys.Status Solidi, (b), 6 i(1974), 637 .

(4) F.C.Crowford：波動下，高橋訳，九善 (1976), 314.

（5）栗林一彦: 金属材料, Vol.17, No.2, (1977).

(6) 岸 楎雄：金属学侌研究会「アコースティックエミ ション技術の基礎と応用」前刷。

(7) Eisenblätter : Proc. 2nd AE Symp., 1974, (Tokyo), 1.
(8) Y.Nakamura, C.L.Veach and B.O. McCauley: Acoustic Emission, ASTM STP 505, (1972), 164.

（9）仰倿搏裕，永田 敬：玨力技術，13卷 2 号, (1975), 17.

(10) K.Ono : Materials Evaluation; August, (1976), 177.

(11) H.Hatano : J. Acoustical Society of America, Vol.57 No.3,(1975), 639.

(12) K. Kuribayashi, H. Tanaka, T. Kishi, R. Horiuchi and K.Katoh : Proc 3rd AE Symp., Tokyo, (1976), 271.

(13) D.O.Harris, A.S.Tetelman and F.A.Darwish: Acoustic Emission, ASTM, STP 505, (1972), 238.

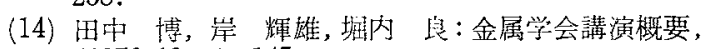
(1976.10月), 145 .

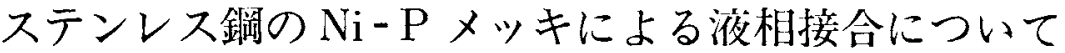

\section{川勝 一 郎* 北山誠 二*}

Ichiro Kawakatsu and Seiji Kitayama : Study on Liquid Phase Bonding of Stainless Steel with Ni-P Plating. For the diffusion bonding of stainless steel used with Ni-P plating in place of insert metal, the weldability and the relation between bonding processes and bonding strength for various bonding times have been investigated. The results obtained are as follows :

(1) Bonding processes are classified into two stages according to the microstructure. The

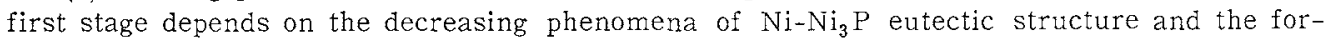
mation of an intermetallic compound at the bonded zone. On the second stage, intermetallic compound can be seen and chemical composition in the bonded zone is homogenized gradually.

(2) Weldability of bonded joints between similar metals at $880^{\circ} \mathrm{C}$ is not so good, but the bonding strength increased with bonding time gradually.

(3) In the case of SUS 304-DCuP 1 joints and SUS 430-DCuP 1 joints, their weldabilities are better than those of SUS 304 and SUS 430 joints. The bonding strength of SUS 304-DCuP 1 joints bonded at $900^{\circ} \mathrm{C}$ for $30 \mathrm{~min}$ is $23 \sim 25 \mathrm{~kg} / \mathrm{mm}^{2}$ and that of SUS $430-D C u P 1$ joints bonded at $900^{\circ} \mathrm{C}$ for $30 \mathrm{~min}$ is $18 \sim 20 \mathrm{~kg} / \mathrm{mm}^{2}$.

(4) In the case of SUS 430 joints, the diffusion phenomenon of phosphorus into the base metal was observed and many intermetallic compounds were formed in the bonded zone. The bonding strength in this case is weaker than that of SUS 304 joints.

(Received February 7, 1977)

\section{I. 緒言}

拡散接合ではその接合性を改善するために，しばしばイ ンサート金属を用いて接合が行なわれている(1)〜(4).この インサート金属は接合面行斿る雨母材の密着性を高める ことが衫らいであり，その用法としては比較的軟質で日材 中に拡散しやすい金属を固相のま使用する場合之母材と 基晶を持つような金属，方るい怔基晶万う材的な金属を用 い，接合解で一端液相を形成する接合法等がある。中でも

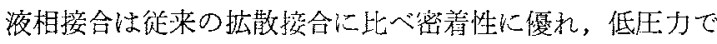

接合することができ，近年特に注目されている。この接合 法の接合過程はるう接と同じと考えられるが(5)，インサー 卜金属が屈材に完全に拡散し，西るいは目材の合金元素が インサート金属吃に搪散し，接合前のインサート金属層を 残さず均一な接合部が得ら机る点で異なる。Duval1(6) 等は $\mathrm{Ni}$ 基の而熱合金を用いた液相接合において，その接合過 程について就明しているが，援合部の性質はインサート材 の種類や接合する和料の組み合わせ等汇よって異なり，そ の挍合過程と機械的強度の関係や按合組織等に䍘しては未 だ明確でない点む多い，そこで本研究では土業的に㳂く用

* 青山学院大学理工学部(College of Science and Engineering, Aoyama Gakuin University, Tokyo) 